\title{
Study on Rural Sports Culture in the Construction of Harmonious New Countryside -- A Case Study of Ningxia
}

\author{
Zhanke $\mathrm{Ma}^{1, \mathrm{a}}$ \\ ${ }^{1}$ Physical Education Institute, Ningxia Normal University, China \\ a530180118@qq.com
}

Keywords: new countryside; sports culture; Ningxia.

\begin{abstract}
This study uses several research methods, including documentary analysis, field study and logical analysis, to analyze the current situation of sport cultural activities in new rural areas of Ningxia under the background of new socialist countryside construction. Then the paper puts forward to the urgent necessity of constructing sports culture in rural areas, and comprehensively analyzes the values and functions of sports culture in the construction of new countryside.
\end{abstract}

\section{Introduction}

The No. 1 Central Document of 2015 proposed that, China needs to promote the construction of new countryside to achieve the integration of urban and rural development. Beautiful countryside is essential to beautiful China. The prosperity of rural areas needs us to promote the construction of new socialist countryside. We should strengthen the guidance functions of planning, improve the infrastructure level of countryside, and promote the equalization of basic public services between urban and rural areas. Then, rural areas can become beautiful homeland in which farmers can live and work in peace and contentment. [1] Earlier, Ningxia government proposed a grand goal of building harmonious and prosperous new Ningxia, and entering a comprehensive well-off society with the whole country. New rural construction not only includes the significant improvement of material living standards, but also requires the establishment of modern, healthy, civilized and scientific cultural lives in new rural areas. As a part of new rural construction and development, sports culture is an important part in constructing spiritual civilization of modern society. It is also an important task when constructing and developing new rural areas. In the process of building harmonious society, sports culture conveys ideas of human oriented and harmonious development. It is consistent with the goal of building harmonious society. Sports activities provide a positive and healthy lifestyle which can promote the harmonious development of the society; sports cultural spirit can inspire citizens' patriotic enthusiasm, and improve the physical quality of the whole nation. The unique functions and significance of sports culture reflects in the process of constructing material and spiritual civilizations in the society.

\section{Research Object and Research Methods}

Research object. Research object of this paper is the current situation of sports culture in new rural areas in Ningxia.

Research methods. Documentary analysis. The author mainly gets information on the development of sports culture in new rural areas of Ningxia from Ningxia library and the library of Ningxia Normal University.

Field interviews. Some new villages are selected from five cities of Ningxia as the interview spots. Field researches on local sports and sports culture are carried out to get first-hand information.

Combining quantitative analysis with qualitative analysis. Collected data are being processed through statistic methods to deeply analyze the current situation and problems in the process of building new rural areas in Ningxia. 


\section{Research Results and Analyses}

Research on the present situation of sports and sports cultural events in new rural areas of Ningxia. Research on the present situation of sports in new rural areas. In recent years, harmonious society and new rural construction become hot social research topics with plenty of fruits. Experts and scholars analyze the culture connotation and development strategies of new rural areas from different perspectives. These studies are the key of constructing new socialist countryside and achieving long-term development goals. Another research focus in recent years is the interpretation of new rural construction from culture perspective. For instance, Jin-long Gao and other researchers believe that the cultural construction is the soul of new countryside construction. Xiao-mao Zhou holds that the new rural culture construction should focus on five new things, namely the cultivation of new ideas, the establishment of new trends, the construction of new environment, the creation of new life, and the building of new carriers. The research center of Ningxia Party School publishes the paper titled The Cultural Construction Need to be Strengthened in New Rural Areas, and puts forwards that strengthening the construction of rural culture is essential for the development of new rural social undertakings. It can guide new rural residents to establish civilized and healthy life style, enhance harmonious relationships between neighborhoods, and effectively improve the quality of new rural residents. Thus, it is very important in the construction of harmonious new countryside.

Ningxia complies with the overall planning of national socialism new countryside and specific situations, and responses actively to national policies. Ningxia has organized immigrant projects include Diaozhuang Resettlement, the "1236 Project" immigration, and immigration programs for eliminating poverty. More than 0.5 million immigrants have been relocated [2]. According to the actual situations of different cities and counties, new rural constructions at different levels are organized and achieved certain results. For example, infrastructure and living environment in rural areas are improved; science and technology are integrated into the construction of new rural areas and gradually improve the quality of rural residents; related systems are gradually improved; residents' cultural lives are more colorful. However, our investigation finds that, the construction of sports culture in most new rural areas is not good. In the surface cultural level of sports culture construction, playgrounds and necessary equipment are not enough; in the shallow cultural level, macro policies and systems are more than micro regulations, and fewer regulations are being implemented; in the middle cultural level, only a small part of new rural residents are willing to participate in physical exercises, since they only have health consciousness instead of scientific exercise consciousness; in the deep cultural level, almost no farmers can actively participate in physical exercise, and there's little sports consumption. The development speed of sports culture is pretty slow [3].

Current situation of sports cultural events in new rural areas of Ningxia. With the increasing development of economic foundation, most people in rural areas begin to take high quality life and scientific exercises into account. The study finds that, a part of sports enthusiasts have emerged in new rural areas. They are willing to provide free guidance to villagers at any time and in any places. They have become social sports instructors, and spread sports culture unconsciously. However, only few of them are professional sports graduates. When teaching new rural residents to take scientific exercise, especially when dealing with issues like specific exercise intensities and sports amounts, their guidance cannot be scientific enough. This study finds that, most new rural residents are eager to be guided by professional sports instructors. The research results of a survey on the sports and cultural activities in new rural areas of Ningxia are shown in table 1: 
Table 1 Satisfaction survey of sports cultural events in new rural areas of Ningxia (\%)

\begin{tabular}{lccccc}
\hline Cities & satisfied & $\begin{array}{c}\text { relatively } \\
\text { satisfied }\end{array}$ & $\begin{array}{c}\text { not very } \\
\text { satisfied }\end{array}$ & unsatisfied & $\begin{array}{c}\text { pretty } \\
\text { unsatisfied }\end{array}$ \\
\hline Xingsheng Village & 5.35 & 22.24 & 16.52 & 39.21 & 16.68 \\
Longhu Settlement & & & & & \\
Area & 4.76 & 21.21 & 15.69 & 35.41 & 22.93 \\
Mumin New Village & 4.39 & 20.01 & 19.82 & 30.57 & 25.21 \\
Shenqiao Village & 3.51 & 18.19 & 16.29 & 39.89 & 22.12 \\
Yangling Village & 3.02 & 10.68 & 12.51 & 48.66 & 25.13 \\
\hline
\end{tabular}

As can be seen from table 2, new rural residents are not satisfied with sports cultural activities. The rate of unsatisfied is as high as $48.66 \%$ in Guyuan. Local governments and sports organizations need to make more efforts to meet the needs of residents' spiritual life. They also need to offer more training courses to social sports instructors and organize more sports cultural activities.

Necessity research of sports culture construction in new rural areas. Sports culture construction in new rural areas is an important part in cultural development in countryside. According to the social development trend of China, the government puts forward to that, new rural construction is an important part of socialist core values; its purpose is to construct relatively systematic concentrated residential areas with national characteristics under the socialist system. In these residential areas, various parts and elements can coordinate with each other; related functions can be optimized continuously. In the construction of new rural areas, Ningxia also actively responds to national policies. The construction of new rural areas is studied from long-term aspects like political, economic and cultural aspects, rather than simply put residents together. As one of the most direct and simple forms of culture communication, sports culture can be spread at any time and in any place; it is an important part of cultural construction, and it is characterized by less investment and quick returns. [7] It plays a special role in cultural development; it is also an indispensable part in new rural construction.

Sports culture construction in new rural areas can effectively improve the overall quality of residents. The rapid development of society cannot be achieved without people, while people's development and civilization cannot be achieved without the society. Only the overall improvement of people's comprehensive quality can promote the civilization progress of society [4]. In our country, the project of new rural construction has just initiated, and it cannot be achieved smoothly and quickly without the participation of farmers, especially new rural residents. The overall quality and civilization degree of them have certain impacts on the construction of new countryside. Ningxia is located in inland areas, which lead to the slow economic development progress. Farmers' living standards and physical qualities are lower than national average standards. Furthermore, material obstacles and monotonous life-style lead to the low cultural qualities of farmers. Sociological theory points out that, people who have been deprived of personal interests may have hostility and hatred toward people who deprived their interests. That phenomenon can create conflicts of farmers' interests. [9] Therefore, the state puts "Three Rural Issues" in an important position. We need to improve the overall quality of farmers as soon as possible. Sports culture, as an important part of cultural development, should play its unique role. Sports culture construction can improve the overall quality of new rural residents, and speed up the development process of civilization in the whole society; it can also reduce crime. Therefore, the new rural construction should attaches great importance to the development of sports culture, in order to improve the overall quality of rural residents and contribute to the development of social civilization. 
Main problems existing in the construction of sports culture in new rural areas of Ningxia. A severe shortage of sports resources in the construction of new rural areas in Ningxia. This research finds that, many new villages do not have sports places or equipment. Some public squares which can be used as playground are far away from new rural areas. Cheng-li Xu believes that these facilities and equipment can promote the farmers' participation in sports activities; they are the material guarantee and carriers of sports culture. [5] Basic sports facilities in new rural areas of Ningxia are scarce seriously, which prevent the development of sports culture. With the rapid development of economy and society, governments of China and the autonomous region have realized the importance of rural sports culture, and increase their investment. But we find that almost all gyms still lie in blueprints. The number of stadiums in cities is increasing conscientiously; while in rural areas, no stadiums or gyms can be found, let alone sports facilities and equipment. The researchers went the selected rural areas for a couple of times; sometimes there was no farmers taking exercises at all. We asked these farmers and concluded the following reasons: living pressure, lack of facilities, healthy exercise consciousness is conflict with space limitation. Therefore, in the construction of harmonious, prosperous and civilized new countryside in Ningxia, the important part of sports culture construction is neglected. Sports resources are in short supply; resources allocation is not reasonable.

Out-dated and incomplete systems in the construction of sports culture in new rural areas in Ningxia. Our country has issued a number of laws and regulations on sports. The complete system of rules and regulations can encourage farmers to take part in sports activities. [6] A healthy and advanced system provides institution guarantee and can actively guides farmers to take part in healthy and scientific physical exercises. With the rapid development of society, China has made some achievements in the construction of sports system in recent years. Especially the increasing mass sports events which provok the government to publish relevant rules and regulations. But these specific regulations get good implementation only in urban areas. New rural areas do not implement these regulations. In rural areas of Ningxia, there is no special sports organization departments or agencies which are responsible for mass sports activities; organizers of sports activities get no attention. Sometimes, leaders and staff from other departments organize some sports activities on impulse, but they are not responsible for organizing or guiding peasants to participate in these sports activities. Sports culture cannot be built in that way. Therefore, when constructing new rural areas in Ningxia, the poor implementation on various sports regulations seriously restricts farmers' participation in sports activities.

Residents' weak sports concepts in the construction of new rural areas in Ningxia. Residents' weak sports concepts also play important roles. Sports values mainly refers to consumers' understanding, evaluations and attitudes towards sports value in the processes of social development, education, health conditions and others. [7] Sports value is the core concept. Although they are related to each other, but to a certain extent, sports value restricts the development of human society, as well as humans' education and health conditions. In other words, the ultimate goals of sports culture are farmers' conscious participation in various sports activities and the in-depth development of sports culture. In this study, researchers find that in Ningxia, new rural farmers do not have purposes in their lives. A few of them have sports awareness, but there's no sports place of equipment; they do not know the values, concepts, functions or purposes of sports, let alone sports consumption. They believe that farm work is sport, and only rich people need to spend money on sports; they do not know how to build their bodies through scientific exercises. These methods of thinking have existed in countryside for a long time, and cannot be changed in short time.

\section{Countermeasures}

Strengthening the construction of sports infrastructure in new rural areas. In order to achieve goals proposed by The Essentials of Nationwide Physical Fitness Plan, relevant departments should increase investment on rural sports infrastructure, and put rural sports infrastructure construction into the overall planning of China. They can set aside some funds to support the construction of rural sports infrastructure, or use multiple channels to raise money. For example, a part of foundations for sports lottery and social welfare lottery can be allocated to build rural sports 
infrastructure. The government can publish relevant preferential policies to encourage enterprises and social organizations to invest new rural construction. Various colorful sports cultural activities should be held frequently to enrich the cultural life of new rural residents, and provide a strong foundation for the harmonious socialist new countryside.

Improving the legal system of sports culture construction in new rural areas. The government should improve existing rules and regulations, and introduce new policies and regulations according to the actual situations of rural areas, such as the regulations of farmers' scientific fitness program and related incentive policies. New rural sports culture activities should be legally guaranteed, which requires supervision and appraisal mechanisms. On the basis of national macro policies, governments of cities and counties ought to publish specific implementation plans and establish institutions of rural sports culture in villages and towns. These institutions should promote the development of sports culture construction under the guidance of sports culture departments at the county level. Governments of cities and counties also need to accelerate the establishment of sports cultural institutions and organizations in villages, formulate detailed assessment indicators, and guide new rural sports cultural activities in rural areas. Then, residents' colorful and healthy spiritual and cultural lives can be protected.

Actively guiding new rural residents to take part in scientific fitness activities; implementing the national fitness program. Governments and organizations at all levels should use various media to publicize healthy and scientific lifestyle, actively enhance farmers' fitness consciousness, and guide farmers to take scientific exercises. Scientific physical exercises are important to healthy lifestyle. Governments and organizations should find out and publicize advanced persons in the area of rural sports, and use them to guide and encourage other villagers. They should contact with relevant urban departments to get opportunities of organizing sports events and carrying out training courses in rural areas, in order to promote the development of rural sports culture, and to help everyone to understand sports cultural activities and take part in scientific exercises. The ultimate goal of these methods is the implementation of "National Fitness Program".

Actively guiding new rural residents to change their sports concepts and adopt healthy life style. Transformation of sports concepts takes a long time. Firstly, related departments need to improve new rural residents' cultural qualities on sports, create sports cultural atmosphere in new rural areas, strengthen the combination of sports culture and new rural cultural construction, and create a good environment for spiritual civilization. Secondly, they need to work together with different fitness associations and organizations to guide farmers to actively participate in scientific and healthy exercises. The cooperation also can cultivate farmers' exercise habits, deepen their understanding of sports functions and values, change their concepts of physical education, arouse their fitness consciousness and guide them to spend money on fitness. Then, farmers' correct fitness concepts can be established. Thirdly, new rural residents' healthy outlook on life should be combined with socialist core values. Farmers need scientific guidance from psychology and physiology aspects. The healthy and happy life of farmers contributes to the realization of a harmonious socialist new countryside and the realization of the great "Chinese Dream".

\section{Acknowledgement}

Fund Project: This project is supported by Foundation for 2014 Provincial Programs of Philosophy and Social Science (Art) in Ningxia. Project No.: 14NXYCGC42.

\section{References}

[1] NetEase network. No. 1 Central Document in 2015. Information on http://money.163.com/15/0201/19/AHD3KP9Q00251OB6.html, 2015.02.01

[2] Q.F.Wang, Strategic choice and routes on the constructing models of new rural areas in Ningxia J. Special Zone Economy, 5(2015) 165.

[3] X. Xiang, Philosophy Culture, Shanghai Popular Science Press, Shanghai, 1997 
[4] X.M. Zhou, Cultural thinking of building new socialist countryside, J. Qiushi Forum. 8 (2005) [5] J.L. Gao, X.Y. Wang, Cultural construction: the soul of new countryside construction, J. Agricultural Archaeology. 3(2006)

[6] L.X. Pei, Z.H. Li, et al. Strategic research on the development of mass sports in China in the next decade, J . China Sport Science and Technology. 9 (2002)

[7] J.J. Zhou, J. Qiu Jun, et al. Development background and mode selection of China's rural sports, J. China Sport Science. 5 (2003) . 